Research Paper

\title{
VALUATION OF BIODIVERSITY, LANDSCAPE CONSERVATION VALUE OF THE MAGROVE ECOSYSTEM IN CAN GIO DISTRICT, HO CHI MINH CITY
}

\author{
Le Xuan Tuan', Tran Quoc Cuong ${ }^{1}$, Phan Thi Anh Dao ${ }^{2}$
}

\author{
ARTICLE HISTORY \\ Received: October 08, 2019 Accepted: November 12, 2019 \\ Publish on: December 25, 2019
}

\section{ABSTRACT}

Utilisation plans of wetland ecosystems in general and mangrove ecosystem in particular are usually determined based on direct use values of the ecosystems such as fisheries, timber, wood rather than indirect and non use values. However, decisions on the use of resources should take into consideration other costs such as opportunity costs and biodiversity conservation willingness so that conservation measures could be developed for sustainable development. From environment economy perspective, non use values can be interpreted as social perception and satisfactory on the conservation of biodiversity at a certain level and social willingness to pay for that. This paper presents the study on valuation of non use values of the Can Gio mangrove biosphere reserve, Ho Chi Minh City. The results show that the non use value of the study area is approximately VND 105 billion per year. The paper also shows the recommendations for managers, policy-makers and researchers in the conservation and sustainable use of resources's Can Gio mangrove ecosystem in the context of climate change and sea level rise.

Keywords: Can Gio mangrove biosphere reserve; Mangrove ecosystems; Economic values; Biodiversity; Landscape conservation.

\section{The concept of total economic value}

From economy perspective, values of resources and environment comprise of various values that accumulate in total economic value TEV. Although the terms has yet to be fully agreed, this set a basis for the interpretation of valuation of values, i.e. based on the interaction between human - valuator and subjects to be valuated.

The total economic value concept was introduced 20 years ago (Pearce and Turner, 1990; Bateman and Willis, 1999; Dinh and Le, 2013). Since then, this concept has become a norm to determine and classify values of ecosystems in general and of mangroves in particular.

In the market economy, there are many kinds of goods traded in the market. They have a certain price, and their value is simple. However, when considering public goods (which do not have market prices and which are under common ownership), the determination of their value in the form of currency will be difficult. One of them is environmental goods. This is a type of goods that is new to research in environmental economics. And to look at the value of this goods fully, we must look at the total economic value (TEV).

Thus, the total economic value (TEV) is the

$\triangle$ LE XUAN TUAN

Corresponding author: tuan.mangrove@gmail.com ${ }^{1}$ Hanoi University of Natural Resources and Environment, MONRE 
sum of the monetary values of the component values of the ecosystem, which is calculated according to the Fig.1.

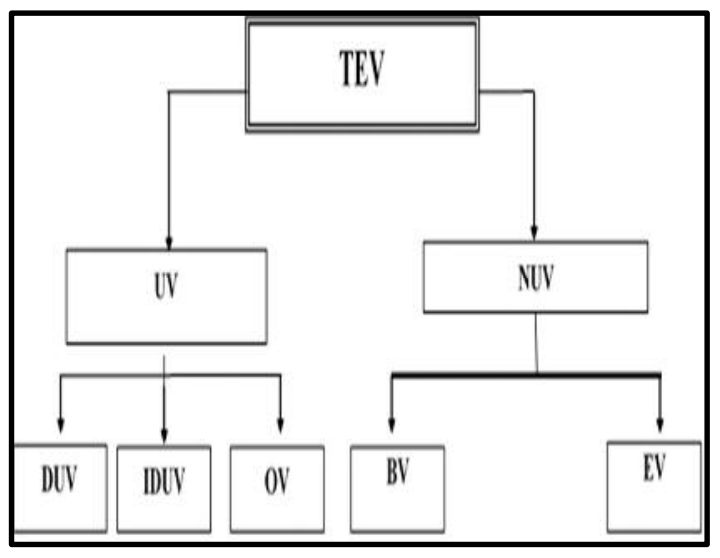

Fig.1.Total economic values.

where $\mathbf{U V}$ is the use value; NUV is the nonuse value; DUV is the direct use value; IDUV is the indirect use value; $\mathbf{O V}$ is the option value; $\mathbf{E V}$ is the existence value; $\mathbf{B V}$ is the bequest value (Turner et al., 2000; Adger et al.,)

- Use value (UV): understood as values used by humans for their own purposes and for the benefit of humans, which can be used in two forms:

+ Direct Use Value (DUV): These are the values that in reality relate to the output of an environmental product that people can establish in the market through price. Usually, the price is established as the real price. That is, if we determine the volume of goods at market prices and subtract the costs, then we will determine its value in real terms.

+ Indirect use value (IDUV): These are values related to the function of the environment in supporting economic activity and human life. It helps people avoid the disaster of nature (floods, climate change ...)

+ Optional Values (OV): Values that depend on the nature or environment of the ecosystem that the assessor needs to consider. It includes the benefits of the resources that serve current human needs and shows the difference between those resources.

- Non-Use Value (NUV): Value is usually in the subconscious of the person who judges it but does not have a place in the market (no market value). This is the most complex issue in environmental economics that is thought to require positive assessments for policy-making. Environmental economists now point out that there are two fundamental values in this group. That is Existence Value (EV), Bequest Value (BV).

+ Existence value (EV): This is the value within the body of things that humans think it can not lose. It must be sustained because of its economic, political and social significance.

+ Bequest value (BV): This value depends on the ability to meet ecosystem services or environmental services for future generations and is within the human horizons of the issue.

Total economic value comprises two main groups, meaning use values and non use values. This paper presents results of valuation of non use values of Can Gio mangrove forest based on contingent valuation method - CVM. Non use value is an indispensable component of total economic value of resources. However, it is difficult to quantify this value as there is no market for environment attributes. It is expected that the study results, under the national projects coded MS: ĐTĐL-G/77 and KC.09.21/16-20, could provide a view of economic values of Can Gio mangrove forest, Ho Chi Minh City.

\section{Methods}

\subsection{Theoretical models}

Contingent valuation method (CVM) is the most common one for valuation of non use values of resources and environment (Dixon, 1989; Turner and Daily, 2008; Turner et al., 2008). There is no market for the non use values and natural resources and environment are pub- 
lic goods that require financial resources to provide an effective amount to the public. Currently, there are various variations of CVM that have been used in the world such as continuous CVM, bidding game, payment card and binary CVM. The binary CVM has been widely used due to sound theoretical basis and model as well as its capability for minimizing biases in field surveys. Therefore, this study used this method to valuate conservation values and non use values of the study area. The theoretical basis of the binary CVM is the Random Utility Model - RUM.

\section{The Random Utility Model - RUM}

Call $V_{i j}$ is utility of the household $\mathrm{j}$ gained from the conservation or improvement of mangrove forest by the solution $i$, in which $i=1$ if the environment is improved and $i=0$ if the environment state is unchanged. $V_{i j}$ is a function of attributes of values of mangrove forest conservation and social - economic characteristics of households:

$$
V_{i j}=V_{i}\left(M_{j}, z_{j}, \varepsilon_{i j}\right)
$$

In which $\mathrm{M}_{\mathrm{j}}$ is the income of the household $\mathrm{j}$; $\mathrm{Z}_{\mathrm{j}}$ is the vector of social - economic characteristics of the household and the attributes of the mangrove forest ecosystem; $\varepsilon_{\mathrm{ij}}$ is random error. The binary question asks interviewees to select either to improve quality of mangrove forest ecosystem or keep it unchanged at the montly cost of $\mathrm{t}$.

Benefits of the market participants are measured by the logarithmic utility model. While the random utility model with the linear income function presumes that the marginal utility of income is unchanged in all answers, the logarithmic utility model allows this variable to be changed as the actual income varies.

Probability for the answer "Yes" for the "change" scenario is calculated as the following: $P\left[Y e s_{j}\right\rfloor=P\left[\left(\alpha_{1} z_{j}+\beta \ln \left(M_{j}-t_{j}\right)+\varepsilon_{1 j}\right) \geq\left(\alpha_{0} z_{j}+\beta \ln M_{j}+\varepsilon_{0 j}\right)\right\rfloor$

$$
P\left[Y_{j} s_{j}\right]=P\left[\left(\alpha z_{j}+\beta \ln \left(\frac{M_{j}-t_{j}}{M_{j}}\right)+\varepsilon_{j} \geq 0\right]\right.
$$

Presume that the $\varepsilon_{\mathrm{j}}$ is the standard distribution with the mean value is 0 and the variance is $\sigma^{2}$, the distribution function of the answer "Yes" is as the following:

$$
P\left[\text { Yes }_{j}\right]=\Phi\left[\left(\alpha z_{j}+\beta \ln \left(\frac{M_{j}-t_{j}}{M_{j}}\right)\right) / \sigma\right]
$$

The $\ln \left(\frac{M_{j}-t_{j}}{M_{j}}\right)$ is called standard income. Vector $\{\propto / \sigma, \beta / \sigma\}$ can be estimated byrunning the model probit/binary on the matrix data
leading to the mean value of WTP: $\left\{z_{j}, \ln \left(\frac{M_{j}-t_{j}}{M_{j}}\right)\right\}$

$$
M D_{\varepsilon}\left[W T P_{j}\right]=M_{j}\left[1-\exp \left(-\frac{\alpha}{\beta} z_{j}\right)\right]
$$

The contingent valuation method was developed by Davis (1963) for marketing analysis and subsequently be applied for environment valuation. By developing scenarios on environment quality and information on behavior and choices of individual consumption in the scenarios, it can be estimated the changes in individual benefits when environment quality changes. From this, individual consumption surplus in assumed market can be calculated. This benefit measures environment values for this individual. This method is usually used for valuating non use values of environment because such values do not have market.

Although CVM has a number of variations and has continuously been developed, it has common procedures i.e. (i) determination of subject group and scope of valuation; (ii) development of questionnaire, testing and adjusting the questionnaire and approaches for information collection; (iii) development of detail questionnaire including information on assumed market, situations, payment medium, willingness to pay; (iv) collection and analysis of information; and (v) calculation of benefit based on model.

\subsection{Study procedures}

\subsubsection{Focus Group discussion - FDGs}

To develop the questionnaire that fits in actual condition, two group discussions were held in the studying area.

The first group discussion was organised for the local government and environment authori- 
ties that comprised the district Department of Agriculture and Rural Development, Department of Environment Management, and the Can Gio biosphare reserve management board. The objective of the discussion was to provide a forum for the authorities to discuss issues related to the use and non use values of the biosphare reserve, pressures and threats imposed on the biosphare reserve, current state and difficulties in management, indentification of stakeholders in mangrove forest ecosystem management. The draft questionnaire was distributed to the authorities for comments.

The second group discussion was organised for some households in the buffer zone of the biosphare reserve. The household's livelihood depends mostly on the mangrove forest. At the discussion, participants were asked about issues related to awareness on values of the mangrove forest, indentification of threats, determination of bids and suggestion of payment medium as well as reasons for willingness and unwillingness to pay. In practice, participants were asked if they are willing to pay an amount of money for conserving biodiversity and landscape of the area. For those whose the answer was "Yes", a second question on the maximum amount of money that they are willing to pay per year was asked. The amounts of money that the participants proposed were VND 30,000, 50,000, 100,000, 150,000, 200,000 and 300,000.

\subsubsection{Determination of sampling size}

Table 1.Household samples in Can Gio District (Can Gio statistics, 2011-2016, 2018)

\begin{tabular}{ccc}
\hline Commune & $\begin{array}{c}\text { People above } \\
15 \text { years old }\end{array}$ & Sample \\
\hline Binh Khanh & 13,931 & 30 \\
An Thoi Dong & 9,068 & 30 \\
Tam Thon Hiep & 4,128 & 30 \\
Ly Nhon & 4,039 & 30 \\
Long Hoa & 8,274 & 30 \\
Thanh An & 3,326 & 30 \\
Can Thanh & 8,391 & 30 \\
Total & 51,157 & 210 \\
\hline
\end{tabular}

There were approximately 51,157 people whose age is over 15 in 5 communes in the studying area. There were approximately 5 people in 1 household, hence there were approximately 5,100 households.

\subsubsection{Questionnaire}

The questionnaire that was used to assess non use values of the Can Gio biosphere reserve comprised 4 main sections. Apart from the introduction on the objectives of the survey and security of information provided, the section 1 provided general introduction to the biosphere reserve, main values of the biosphere reserve and asked interviewees about attitude and awareness on the conservation of values of the biosphere reserve as well as their participation in conservation process.

Section 2 comprised questions on willingness to pay of people for conserving biodiversity values and landscape of the biosphere reserve. At the start, with supports provided by mangrove forest conservation expert, a conservation scenario was developed and introduced to people. The scenario introduced typical characteristics, general data on biodiversity values, landscape and ecosystems of the Can Gio biosphere reserve as well as relationship between biodiversity values and other value groups. Subsequently, people provided current threats on biodiversity and landscape conservation in the biosphere reserve (shrimp farming, environment pollution, and illegal exploitation). These were reasons that caused degradation of biodiversity and ecological values and would continue to be the threats if control and management measures are not taken. Therefore, there is a need for conservation and management measures with participation of stakeholders including local people for biodiversity and landscape to be maintained.

After the conservation scenario had been introduced, people were asked if they are willing to pay a certain amount of money for biodiversity and landscape conservation. The amount of money that they are willing to pay was randomly selected from 6 levels determined in the pilot survey. Contribution medium identified was a local environment fund. Debriefing questions 
were asked after the questions on willingness to pay to determine reasons for the answers "willing to pay" and "unwilling to pay".

The last section of the questionnaire comprised questions on demography such as sex, qualifications, the number of family members and incomes. The question on the incomes provided a range of household incomes for the interviewees to select. This approach demonstrated its effectiveness in Vietnam rather than open question. The mean incomes were to be selected for statistics.

\section{Biodiversity values of the Can Gio man- grove biosphere reserve}

\subsection{Biodiversity value of Can Gio}

Can Gio mangrove forest was recognized as protection forest in 1991. It was recognized as biosphere reserve by UNESCO in 21 January 2000. It is the most beautiful mangrove forest in Southeast Asia that was recovered after it had been destroyed by toxic chemical in the war (UNESCO/MAB, 2000). Before 30 April 1975, the Can Gio mangrove forest was 40,000 ha area; thick canopy with forest tree above $25 \mathrm{~m}$ in height and at $25-40 \mathrm{~cm}$ diameter. Rhizophora apiculata was predominant species together with other communities including Sonneratia alba, Avicennia alba, R. mucronata, Bruguiera spp., Xylocarpus spp., Lumnitzera spp., Phoenix paludosa, Excoecaria agallocha, etc. Apart from mangrove forest, the Can Gio district also had bazan hills such as Giong Chua, Giong Ao, etc. that were home to weed, shrub and recovered tropical raining trees. From 1964 to 1970, American sprayed defoliation chemical along the Long Tau river and to forest ward hundreds of meter. Defoliation chemical that had been sprayed several times for almost 10 years (1964 - 1972) destroyed more than $80 \%$ area of the forest. R. apiculata and R. mucrolataspecies almost disappeared. Some trees of Ceriops spp. and Excoecaria Agallocharecoveredhere and there along canals. There were Mam in tidal zone, and
Phoenix paludosa, Acrostichum aureum, Gymnanthera mitida, Derris trifoliate, Azima sarmentosa, Pluchea indica and Clerodendrum inerme, etc. in upper land. After the liberation of the South in 30 April 1975, Can Gio mangrove forest belonged to Duyen Hai District, Dong Nai Province. In 1978, the Duyen Hai District was handed over to Ho Chi Minh City with total area of 71,361 ha in which 34,468 ha was mangrove forest and forestry land. Since 1984, some trees such as Intsia bijuga, Ceriops tagal, C. decandra, Lumnitzera racemosa, Xylocarpus granatum, Thespesia populnea, etc. were plantedto re-green upper land. Aquatic species composition is diverse in Can Gio forest. There are more than 130 algae species belonging to three phyla i.e. Bacillariophyta, Pyrrophyta and Cyanophyta, in which Bacillariophyta predominates. Aquatic invertebrate fauna comprises 700 species belonging to 44 families, 19 orders, 6 classes, 5 phyla. Fish fauna comprises over 137 species, belonging to 39 families and 13 orders (Tuan, 2016; Tuan et al., 2018). Terrestrial vertebrate comprises 9 amphibian species, 31 reptile species and 4 mammal species, in which 11 reptile species are listed in the Vietnam Red Data Book such as Gekko gecko, Varanus salvator, Python molurus, Python reticulates, Bungarus fasciatus, Naja naja, Ophiophagus hannah, Chelonia mydas, Crocodylus porosus, etc. Bird fauna comprises 130 species, belonging to 47 families and 17 orders, in which 51 species are water bird and 79 species live in different habitats.

\subsection{Identify important economic values of Can Gio mangroves}

The coastal mangroves of Can Gio provide a wide range of economic values for the people and the community. The following important economic values were identified through the author's research process by means of consultations with experts, people with direct livelihoods and mangrove resources, secondary literature study and primary, combined with a comparison with some other mangrove ecosystems that have the same basic natural conditions as the study area. 
A number of other economic value types, though present in the field, are not considered important and will not be listed here (Table 2).

Table 2. Important economic values of Can Gio mangrove forest

\begin{tabular}{|c|c|c|}
\hline Direct use value & $\begin{array}{l}\text { Indirect use } \\
\text { value }\end{array}$ & $\begin{array}{l}\text { None-use } \\
\text { value }\end{array}$ \\
\hline $\begin{array}{l}\text { - Tidal fishing } \\
\text { value } \\
\text { - Honey value } \\
\text { - Aquaculture } \\
\text { value (shrimp, } \\
\text { sea bass, clam) } \\
\text { - Tourism value }\end{array}$ & $\begin{array}{l}\text { - Protection } \\
\text { value } \\
-\mathrm{CO}_{2} \\
\text { absorption } \\
\text { value } \\
\text { - Values } \\
\text { environment }\end{array}$ & $\begin{array}{l}\text { Biodiversity } \\
\text { conservation } \\
\text { value }\end{array}$ \\
\hline
\end{tabular}

\section{Non use values of the Can Gio mangrove forest ecosystem}

Non use values are more abstract than use value. Non use values are intrinsic value of mangrove forest and comprise existence values and bequest values.

Non use values are part of values of environment asset that do not derive from direct or indirect consumption of goods and services provided by environment asset. The values reflect choices of human, care and respect rights and existence of other species. The values are also called awareness values on the existence of other species or of ecosystem. Non use values comprise the following components:

- Bequest values are satisfaction in individual feeling in knowing that resources is to be handed over and received by future generations. The values are usually measured by individual willingness to pay for conserving resources for future generation.

- Existence values are satisfaction in individual feeling in knowing that attributes of mangrove forest exist in a certain state and are usually measured by individual willingness to pay for having this state. In general, society also gain benefits from environment goods apart from direct or indirect uses (Barbier, 1989; ADB, 1996; Turner et al., 2007). This is not a tangible consumption but individuals obviously feel happy in knowing that the resources still exists. It is difficult to explain why society appreciates these values. However, we know that society is willing to pay for conserving this asset. In such cases, benefits of society simply derive from knowing that the asset exists and is protected. This component of total values is known as existence values.

Non use values of mangrove forest lie in individual feeling, knowledge and satisfaction in knowing that mangrove forest exist and to be handed over to future generation at a certain state. As mentioned above, the study selected mangrove forest biodiversity conservation and landscape values for valuation. The method used was CVM. The exercise was undertaken based on data gained from interviews by the questionnaire.

\section{Valuation results}

\subsection{Estimation results}

The Random Utility Model was used to estimate WTP of households for conserving biodiversity values in Can Gio. Theoretical basis and economic nature of the model were presented in Section 2.1. In practice, the study applied the Binary Logistic model and the Maximum Likelihood estimation to estimate expected values of willingness to pay for conserving biodiversity and landscape in the Can Gio biosphere reserve. Factors influencing payment capability were also analyzed. In the study, two models were used to estimate variation range of expected WTP.

Table 3. Descriptions of WTP estimation models (Analysis of survey data, 2012, 2016, 2018)

\begin{tabular}{cclc}
\hline No & Models & Explanation & Sample size \\
\hline 1 & A & $\begin{array}{l}\text { Payment } \\
\text { biodiversity } \\
\text { conservation model } \\
\end{array}$ & 210 \\
2 & B & $\begin{array}{l}\text { Payment for landscape } \\
\text { conservation model }\end{array}$ & 210 \\
& &
\end{tabular}


WTP practice model is a probability function on payment for biodiversity and landscape conservation:

$\operatorname{Pr}($ Yes $)=\mathrm{a} 1+\mathrm{b} 1 \mathrm{BID}+\mathrm{b} 2 \mathrm{EDU}+\mathrm{b} 3$

MEMBER + b4 INCOME + b5 AGE + b6 SEX (6)

Table 4. Descriptions of variables in binary CVM model (Analysis of survey data, 2012, 2016, 2018)

\begin{tabular}{|c|c|c|}
\hline Variables & Explanations & Codes \\
\hline $\operatorname{Pr}($ Yes $)$ & $\begin{array}{l}\text { Probability for } \\
\text { willingness to pay a } \\
\text { certain Bid for } \\
\text { biodiversity and } \\
\text { landscape } \\
\text { conservation }\end{array}$ & $\begin{array}{l}\text { Willingness to pay } \\
=1 \\
\text { Unwillingness to } \\
\text { pay }=0\end{array}$ \\
\hline BID & $\begin{array}{l}\text { Bid proposed and } \\
\text { asked if people are } \\
\text { willing to pay that } \\
\text { Bid (VND } \\
\text { thousand/year) }\end{array}$ & $\begin{array}{lr}\text { Bid levels: VND } \\
30,000, & 50,000, \\
100,000, & 150,000, \\
200,000 & \text { and } \\
300,000 & \end{array}$ \\
\hline EDU & $\begin{array}{l}\text { Education (school } \\
\text { years) }\end{array}$ & $\begin{array}{l}\text { Continuous } \\
\text { variable }\end{array}$ \\
\hline MEMBER & $\begin{array}{l}\text { Number of people in } \\
\text { family }\end{array}$ & $\begin{array}{l}\text { Continuous } \\
\text { variable }\end{array}$ \\
\hline INCOME & $\begin{array}{l}\text { Household income } \\
\text { (VND/year) }\end{array}$ & $\begin{array}{l}\text { Continuous } \\
\text { variable }\end{array}$ \\
\hline AGE & Age of interviewee & $\begin{array}{l}\text { Continuous } \\
\text { variable }\end{array}$ \\
\hline SEX & Sex of interviewees & $\begin{array}{l}\text { Male }= \\
\text { Female }=0\end{array}$ \\
\hline
\end{tabular}

Table 5. Results of model

\begin{tabular}{lll}
\hline \multicolumn{1}{c}{ Variables } & \multicolumn{1}{c}{ Model A } & \multicolumn{1}{c}{ Model B } \\
\hline EDU (mean) & $8,65(2,70)$ & $7,59(3,5)$ \\
$\begin{array}{l}\text { MEMBER } \\
\text { (mean) }\end{array}$ & $3,94(2,15)$ & $4,1(1,27)$ \\
INCOME & $23170(7318)$ & $25041(7241)$ \\
(mean) & & \\
AGE (mean) & $38,94(15,76)$ & $34,59(14,02)$ \\
SEX (mean) & $0,46(0,30)$ & $0,53(0,22)$ \\
Model & & \\
Constant & $1,124(0,653)$ & $1,030(0,67)$ \\
BID & $-0,04 * * *(0,006)$ & - \\
& & $0,036 * * *(0,008)$ \\
EDU & $-0,013(0,059)$ & $-0,016(0,08)$ \\
MEMBER & $0,060(0,045)$ & $0,067 *(0,077)$ \\
INCOME & $0,000 *(0,000)$ & $0,000(0,000)$ \\
AGE & $0,005(0,008)$ & $-0,009(0,01)$ \\
SEX & $0,186(0,191)$ & $0,202(0,271)$ \\
-2 Log likelihood & 633,730 & 323,064 \\
\hline
\end{tabular}

Note: (...): Standard deviation

$* * *:$ Error $=1 \%{ }^{* *}:$ Error $=5 \%{ }^{*}:$ Error $=10 \%$.
Results gained from processing the model by SPSS software with binary logistic are as follows.

In all models, coefficient of the BID variable is negative and valid at error $=1 \%$. This in accordance with theory that when BID increases, probability of willingness to pay decreases.

INCOME variable is positive and valid at error $=5 \%$ in model A. Hence, in this model, individual income slightly influences willingness to pay for biodiversity conservation. When household income increases by VND 1,000/year, probability of payment for a BID level raises less than $1 / 1,000$.

Expected WTP for biodiversity and landscape conservation of each model was estimated by theoretical function and presented in the Table 5.

$$
E_{\varepsilon}\left[W T P_{j}\right]=M_{j}\left[1-\exp \left(-\frac{\alpha}{\beta} z_{j}+\frac{1}{2} \frac{\sigma^{2}}{\beta^{2}}\right)\right]
$$

The estimation result shows that expected WTP for biodiversity conservation is VND 126.3 thousands/year and WTP for landscape conservation is VND 78.7 thousands/year.

Therefore, if the number of people above 15 years olds in the studying area is 51,517 , the estimated total biodiversity conservation value of Can Gio is VND 64.6 billions/year and estimated total landscape conservation value is VND 40.26 billions/year.

Table 6. Estimation of WTP from the models (Analysis of survey data (2012-2016, 2018))

\begin{tabular}{cccl}
\hline No & Models & $\begin{array}{l}\text { Expected WTP } \\
\text { (VND } \\
\text { thousands per } \\
\text { year) }\end{array}$ & $\begin{array}{l}\text { Generalization } \\
\text { (VND } \\
\text { thousands per } \\
\text { year) }\end{array}$ \\
\hline 1 & $\begin{array}{c}\text { A } \\
\text { (biodiversity } \\
\text { conservation) }\end{array}$ & 126.3 & $64,611,291,000$ \\
2 & $\begin{array}{c}\text { B (landscape } \\
\text { conservation) }\end{array}$ & 78.7 & $40,260,559,000$ \\
\hline
\end{tabular}

5.2. Total non use value of Can Gio mangrove forest

Non use value of Can Gio mangrove forest is presented in the Table 7. 
Table 7. Non use value of theCan Gio mangrove forest (Analysis of survey data, 2012,

\begin{tabular}{llc}
\multicolumn{3}{c}{ 2016, 2018) } \\
\hline No $\quad$ Economic values & $\begin{array}{c}\text { Annual total } \\
\text { value (VND } \\
\text { billions) }\end{array}$ & $\begin{array}{c}\text { Percentage in } \\
\text { total value }\end{array}$ \\
\hline $\begin{array}{l}\text { Non use values } \\
1 \quad \begin{array}{l}\text { Biodiversity } \\
\text { conservation value }\end{array}\end{array}$ & 64.61 & 2.63 \\
$2 \quad \begin{array}{l}\text { Landscape } \\
\text { conservation value }\end{array}$ & 40.26 & 1.64 \\
$\begin{array}{l}\text { Total non use value } \\
\text { TOTAL ECONOMIC }\end{array}$ & 104.87 & 4.27 \\
VALUE (TEV) & $2,460.23$ & 100 \\
\hline
\end{tabular}

\section{Conclusions and Recommendations}

Valuation of non use values of wetlands in general and the Can Gio mangrove forest in particular is significant in policy and decision making on resources use and management. From economic perspective, non use values are interpreted as social feeling and satisfaction in maintaining biodiversity values at a certain state and society's willingness to pay for that. The results of the valuation of non use value of Can Gio mangrove forest biosphere reserve by CVM method using questionnaire in 7 communes show that non use value of the studying area is approximately VND 105 billions/year, making up $4.27 \%$ total economic value of the area. The results lead to the following recommendations:

Firstly, selection of utilization plan of mangrove forest in land use planning should take into consideration of non use values of mangrove forest ecosystem. This helps to reflect practical effectiveness of the resources utilization plan from social perspective. Wetland utilization plans usually take into consideration only direct values of the wetland ecosystem such as shrimp, fish, and wood rather than indirect and non use values. However, resource utilization always has opportunity costs and biodiversity will possibly be degraded if conservation plan is not put in place in development plan.

Secondly, results of valuation of non use values of wetland ecosystems provide resources and environment management authorities with input data to develop conservation and sustainable management mechanisms such as Payment for Environment Services (PES). PES is provided in the Law on Biodiversity Conservation as a market based tool to facilitate biodiversity conservation by influencing economic motivation of stakeholders.

Thirdly, information on non use values of wetland resources in general and mangrove forest in particular helps authorities to develop database on the wetland ecosystem. The information plays an important role as a basis for resolving conflicts in wetland uses. The results play the important valuable which provide the manager, researchers with practical and scientific basis to propose policies for sustainable management, exploitation, use of mangrove ecosystem resources to cope with climate change and sea level rise.

Finally, authorities can use information on biodiversity value conservation for communication and education campaigns to raise awareness, attitude and behavior on conservation and sustainable management of wetland ecosystem in general and mangrove forest ecosystem in particular.

\section{References}

1. ADB, 1996. Economic Evaluation of Environmental Impacts: A Workbook. Environment Division, Office of Environment and Social Development. Asian Development Bank. Manila, Philippines.

2. Adger, W.N., Brown K., Cervigni R., Moran D., 1995. Total economic value of forests in Mexico. Ambio, 24(5): 286-296.

3. Barbier, E.B., 1989. The economic value of ecosystems: I-tropical wetlands. LEEC Gatekeeper Series, No. 89-01. London Environmental Economic Centre.

4. Bateman, I.J., Willis. K.G., 1999. Valuing Environmental Preferences. Oxford University Press, UK.

5. Can Gio statistics. 2018. Can Gio People's 
Committee, 2011-2016.

6. Davis, R. K. (1963), "The Value of Outdoor Recreation: An Economic Study of the Maine Woods." Dissertation, Harvard University.

7. Dinh,D.T., Le H.T.,2013. Environment and Resources Valuation: From Theory to Practice in Vietnam.Transportation Publishing House.

8. Dixon, J.A., 1989. Valuation of Mangroves. Trop. Coastal Area Manag. Manila 4 (3), 2-6.

9. Le,D.T., 2016. Human resources of Can Gio Mangroves, Ho Chi Minh City. Publishing house for Science and Technology, Hanoi, Vietnam.

10. Le,X. T., 2016. State-level Project, Code: DTDL. 2011/G77: Study on the impact of Vung Tau - Go Cong seadyke to the coastal ecosystems.

11. Le X.T., Nguyen, H.Y., Phan, T.A.D., Mai, S.T., 2018. Coastal ecosystem of Vietnam, Publishing house for Science and Technology, Hanoi, Vietnam,pp: 166-177.

12. Pearce, D., Turner, K., 1990. Economics of Natural Resources and the Environment.
Hemel Hempstead: Harvester Wheatsheaf.

13. Turner, R.K., Adger, W.N., Brouwer, R., 1998. Ecosystem services value, research needs, and policy relevance: a commentary. Ecological Economics, 25: 61-65.

14. Turner, R.K., Burgess, D., Hadley, D., Coombes, E., Jackson, N., 2007. A cost-benefit appraisal of coastal managed realignment policy. Global Environmental Change-Human and Policy Dimensions, 17: 397-407.

15. Turner, R.K., Daily, G.C., 2008. The ecosystem services framework and natural capital conservation. Environmental \& Resource Economics, 39: 25-35.

16. Turner, R.K., Georgiou, S., Fisher, B., 2008. Valuing Ecosystem Services: The Case of Multi-functional Wetlands. Earthscan: UK.

17. Turner, R.K., 1988. Wetland conservation: economics and ethics. In: Collard, D., et al. (Eds.).Economic, Growth and Sustainable Development. Macmillan, London, pp:121-159.

18. Nguyen, H.T., Phan, N.H., Le, T.C., 2000. Can Gio Mangrove Biosphere Reserve Ho Chi Minh City. UNESCO, pp: 43. 